potential in educational and professional activities. The first pedagogical condition involves the person-centered educational process and educational environment planning. The second condition is implemented by means of using active teaching methods in the educational process aiming to ensure close relationship between training theory and practice for future professional activities of military psychologists. The third pedagogical condition of future reserve officers-psychologists' military competence formation is implemented through the development of students' self-consciousness, reflection, creative skills, volitional qualities and mechanisms of volitional self-regulation, etc. The above mentioned pedagogical conditions are considered to be the core of the developed technique aimed at the development of future reserve officers-psychologists' military competence formation, which will be described in the further studies. Besides, the further research involves suggesting recommendations for scientific and pedagogical staff in using this technique.

Keywords: special military competence, future reserve officers-psychologists, student, pedagogical conditions.

Подано до редакиії 05.12.2016

Рецензент: д. пед. н., проф. І. Л. Гончар

UDC: $371.68: 373.6: 37.032$

\author{
Nadiia Grytsyk, \\ PhD (Candidate of Pedagogical Sciences), associate professor, \\ Department of Foreign Languages, \\ Chernihiv National Pedagogical University named after T. G. Shevchenko, \\ 53, Hetmana Polubotka Str., Chernihiv, Ukraine
}

\title{
CONTENT AND LANGUAGE INTEGRATED LEARNING: APPROACH TO TEACHING ENGLISH FOR SPECIFIC PURPOSES
}

\begin{abstract}
"CLIL - Content-language integrated learning - refers to situations where subjects, or parts of subjects, are taught through a foreign language with dual-focused aims, namely the learning of content and the simultaneous learning of a foreign language."

David Marsh, 1994, Finland
\end{abstract}

The subject of this paper is presenting the description of CLIL - Content and Language Integrated Learning - in the context of language learning in higher educational institutions. CLIL describes a pedagogical approach in which the language and subject area content are learnt in combination. The generic term CLIL describes any learning activity where the language is used as a tool to develop new learning from a subject area or theme. CLIL is a special approach to delivering content in education: a non-linguistic subject is not taught in a foreign language, but by means of a foreign language. Through this kind of educational provision, students gain knowledge of some special subjects in the curriculum, at the same time mastering their language skills. CLIL is based on the principles of ' $4 C$ ' (communication, content, cognition, culture). CLIL is promoted as means of solving problems as case study. The author of this article regarded CLIL as an efficient instrument of learning ESP as a means of motivating students for further studies. The article highlights CLIL as integral part of ESP course. The article touches upon the issues related to the opportunity for implementing these methods that are widely used in the European Union in higher education in Ukraine, the conditions under which these methods can be realised are determined. The author also makes conclusion that integrating CLIL approach in ESP course will make it possible to enhance the university foreign language training and improve the quality of the teaching process arrangement.

Keywords: content and language integrated learning (CLIL), principles of CLIL, English for Specific Purposes (ESP), foreign language (FL), General English (General English), higher educational institutions.

Introduction. In the modern world, with the development of international relations in the political, socioeconomic and cultural spheres of society, the role of the English language, which is considered to be the most accepted form of communication in the business world, significantly increases. The key to successful professional activity of any specialist is the knowledge not only of General English (GE), but also acquisition of professional foreign language (FL) competence. That is why, such discipline as English for Specific Purposes (ESP) is taught at higher educational institutions for students of non-linguistic specialities.

In this context ESP approach plays an important role that helps to form students' ability of FL communication in specific professional, business, scientific spheres and situations considering the features of professional thinking. The study of foreign (S. Burger, M. Wesche, M. Migneron, N. Cloud) and Ukrainian (O. Tarnopolskyi, S. Kozhushko, Z. Korneva) scientists' works shows that a 
great amount of data has been achieved in the field of vocationally-oriented language learning.

The researchers note that the performance models do not always correspond to the stated objectives, so there is a contradiction between the social order for graduates' good knowledge of a foreign language in professional communication (ESP) and the lack of modern educational technologies.

The foreign researchers in the field of foreign language teaching (LSP - Language for Specific Purposes) emphasise the importance of active development of the following aspects of FL for professional growth of specialists in the conditions of globalisation: speaking and listening for presentations, teleconferences and communication with colleagues and clients by phone; reading and writing - for writing and studying e-mails, reports, memos, meetings, etc. [12].

It should be pointed out that very often the ESP course that acquaints students with their profession is usually taught during the $1^{\text {st }}$ and $2^{\text {nd }}$ years of studying. In fact, the restricted amount of English classes at nonlinguistic universities only complicates the necessity for teaching professionally oriented English in order to develop all the necessary English communication skills and competences as well as to reach the target level B2, which is the standard for the degree of a bachelor [7].

Therefore, by the time of graduation, students have mastered the language of the speciality in the amount that is insufficient for a productive and effective professional communication and have lost previously acquired communicative skills without constant practice, which prevents successful professional development of specialists.

In this regard very interesting and actual is modern methodology Content and Language Integrated Learning (CLIL). According to K. Bentley [1], CLIL is a new approach in education where subjects are taught through the environment of FL.

CLIL approach is widely used in teaching practice at non-linguistic higher educational institutions and is much supported by the European Commission. This approach is focused on studying the main subjects in a FL by the students. Consequently, learning a foreign language in a non-linguistic higher educational institution implies a real-life setting which includes the situations closely connected with the students' professional interests [2].

The European Commission considers CLIL as an integral part of contemporary school education in most EU countries, as a great opportunity for improving language teaching in most EU countries, as well as a good opportunity for "exposure to the language without requiring extra time in the curriculum" [2, p. 8].

The purpose of the current paper is to look at the advantages and reasons for integrating CLIL approach into teaching ESP course.

Defining Content and Language Integrated

\section{Learning}

In foreign pedagogical literature there are many different definitions of CLIL. In the present article we relied on the definition of CLIL that was introduced in 1994 by the researcher in the field of multilingual education David Marsh in the process for the coordination of studies on the state of language education in Europe [8]. CLIL is a dualfocused educational approach in which an additional language is used for the learning and teaching of both content and language. That is, the teaching and learning process is focused neither on the content, nor on the language only. Each is interwoven, even if the emphasis is greater on one or another at a given time [3].

The scientist says that we can speak about CLIL in cases when we deal with subjects or certain topics, the study of which is carried out in a FL and thus has two objectives: studying the content of this discipline and the simultaneous learning of a foreign language. The implementation of CLIL aimed at the intensification of the educational process, in which FL teacher uses interdisciplinary topics in FL classroom or when teaching a discipline, is carried out in FL.

British Council interprets CLIL approach as the competence-based language teaching; its main idea is the simultaneous acquisition of language and the subject, that is, "to use the language to learn, and learn to use the language", and notes its increasing popularity as one of the leading approaches to professional education in the European universities. CLIL encourages the introduction of programmes aimed at the development of interpersonal, intercultural, communicative, and language skills that are in demand among today's employers into the curricula of the university.

\section{Underlying principles of CLIL}

Some of the underlying principles of CLIL used in the classroom are: 1) the language is used to learn as well as to communicate; 2) the subject matter determines the language needed to be learned suggests the 4Cs Approach to Integrated Curriculum (figure 1), displaying how these principles interact with each other [8].

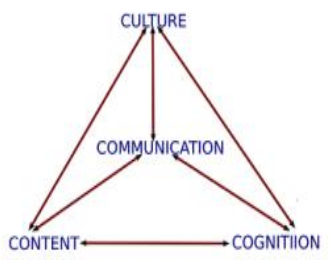

Figure 1. 4Cs Approach to Integrated Curriculum 
It is worth saying that Communication is located in the centre of the pyramid, it means that other components (Content, Cognition, Culture) should be implemented through communication and socialising [4].

So as you see, a successful CLIL lesson should combine elements of the four principles below:

- CONTENT (integrating content from across the curriculum though high quality language interaction);

- COGNITION (engaging learners through creativity, higher order thinking and knowledge processing);
- COMMUNICATION (using language to learn and render ideas, thoughts and values);

- CULTURE (interpreting and understanding the significance of content and language and their contribution to identity and citizenship) [4].

According to Mehisto, Marsh and Frigols [10, p. 29] five important core features can be listed as follows (Table 1):

Features of CLIL Methodology

Table 1

\begin{tabular}{|l|l|}
\hline $\begin{array}{l}\text { Multiple focus ap- } \\
\text { proach }\end{array}$ & $\begin{array}{l}\text { A high degree of integration should be achieved between language and content classes } \\
\text { and among different subjects. }\end{array}$ \\
\hline $\begin{array}{l}\text { Safe and enriching } \\
\text { learning environ- } \\
\text { ment }\end{array}$ & $\begin{array}{l}\text { CLIL teachers should encourage students to experiment with language and content pro- } \\
\text { viding guided access to authentic materials and learning environments. }\end{array}$ \\
\hline Authenticity & $\begin{array}{l}\text { Connections between learning and students' lives should be provided regularly in CLIL } \\
\text { activities as well as connections with other speakers of the CLIL language. Current } \\
\text { materials from media or other sources should be used as often as possible. }\end{array}$ \\
\hline Active learning & $\begin{array}{l}\text { Students have a central role in CLIL lessons: their activities should be based on a peer } \\
\text { cooperative work and they should help set content, language and learning skills out- } \\
\text { comes. Finally, they should communicate more than the teacher who acts as a facilitator. }\end{array}$ \\
\hline Scaffolding & $\begin{array}{l}\text { One of the teacher's roles is to support students' language needs basing on their existing } \\
\text { knowledge, repackaging information in user-friendly ways and responding to different } \\
\text { learning styles. }\end{array}$ \\
\hline Cooperation & $\begin{array}{l}\text { A high degree of cooperation among different teachers is recommended when planning } \\
\text { lessons, and it is often considered useful to involve parents and/or the local community. }\end{array}$ \\
\hline
\end{tabular}

A typical CLIL lesson plan consists of stages specifically designed to perform the following activities:

- checking previous knowledge;

- practicing content language;

- expanding vocabulary;

- consolidating knowledge;

- summarising skills;

- applying the new knowledge;

- checking and correcting errors.

To practice content language, it is necessary to design stages focused on speaking interaction and/or on developing receptive skills like listening and reading. Depending on the topic, it might be important to develop the production of language even in written form.

CLIL is seen as a completely new experience compared to the traditional way of FL studying, since the content of the subject and language are developed at the same time. This approach encourages the language teacher to learn more about the subject areas of their students, and subject teachers to learn a FL.

There are a large number of publications [12] that prove the necessity of the implementation of this technique in training process of higher educational institu- tions, provide recommendations for the selection of educational information and the educational process.

Foreign authors argue that students studying on the basis of the CLIL are able to express their thoughts accurately, which in turn leads to mental stimulation of project activities; they work harder, show a higher tolerance for failure, and have a high level of academic competence $\mathrm{J}$. Nixon believes that, "when teaching a subject by means of a foreign language, we not only simulate the conditions of extracurricular communication: we raise students' confidence and expand their knowledge, satisfy curiosity, and increase motivation" [11].

The practice of CLIL is a complex process and is implemented in many models such as: soft CLIL (teaching some topics from the content of the special disciplines in the FL); hard CLIL (a partial immersion program where more than half of the disciplines are taught in a FL); modular CLIL (the subject is taught in a FL for a certain number of academic hours) [15].

As for teaching ESP in the majority of Ukrainian universities, we can compare CLIL with the second model. Traditionally, learning involves two interrelated aspects - the language for common GL and LSP. In addi- 
tion, the requirements for FL training at the university aimed at the development of common cultural and professional competences of students are equal to underlying principles of CLIL (4 Cs) as well as the principle of the so-called "language triangle" of CLIL (the language triptych), when temporary learning and using of a language can involve several interrelated structural aspects of language learning (language of learning), language for learning (language for learning) and language through learning (language through learning) [5].

And within this context, case study becomes an appropriate tool for teaching CLIL in an integrated way and at the same time follows the main principles of CLIL methodology defined by Mehisto, Marsh, Frigols [10] and can be qualified as CLIL way of teaching. Its main principles include:

1. Authenticity. It is an authentic case from the real world, students take on roles of authentic business world (company owners and consultants), the case analysis follows "real world" situation.

2. Multiple focus. The main focus in a case study is on: 1) content understanding and analysis (development of cognitive skills through the analysis of the case content, choice of relevant information for the question assigned); 2) group work and inter-personal communication; 3) presentation and discussion skills; 4) foreign language skills; 5) learning to learn skills (time management, group work, information management); 6) skills for information search and presentation preparation.

3. Active learning. The learners are actively involved both in the preparation and presentation stages; they are in the centre of the project taking all responsibility for the running of the whole case. They are also responsible for the development of criteria for peer evaluation and then evaluating their colleagues.

4. Safe learning environment is created by familiar classroom setting and peer participation, followed by selfand peer evaluation.

5. Scaffolding. Consultations with the teacher and colleagues, all class discussion of the case prior to assigning the tasks, vocabulary clarification and understanding

\section{ЛІТЕРАТУРА}

1. Bentley K. The TKT Course CLIL module / K. Bentley. - Cambridge: CUP, 2010. - 124 p.

2. Commission of the European Communities Promoting Language Learning and Linguistic Diversity: An action plan 2004-2006. - Brussel, 2003.

3. Coyle D. CLIL Content and language integrated learning / D. Coyle, Ph. Hood, D. Marsh. - Cambridge: CUP. -2010 .

4. Coyle D. Theory and planning for effective classrooms: supporting students in content and language integrated learning contexts / D. Coyle // Learning through a foreign language; ed. by J. Masih. - London: CILT. - 1999

5. Coyle D. Evaluating the impact of CLIL programmes: Content and language integrated learning. are conducted before the project discussion in class. There are also sample opportunities for the students to clarify any difficulties with peers, as the project is extended over several weeks in time, so that sufficient time is devoted to the preparation stage.

A case study provides sample opportunities to develop and integrate skills, knowledge and attitudes, i. e. develop learners' competences [3].

Conclusion and recommendations. Taking into consideration all the mentioned above, today we can still witness that demand for ESP continues to increase and expand throughout the world [6]. Learners need new courses matching their ever growing needs and requirements resulting from what the labour market demands. For this reason, new CLIL approach was integrated in ESP course end of the 20th century. This makes teaching ESP courses more meaningful and effective. Learning ESP in the framework of CLIL helps students to develop the specific way of thinking and to be ready to perform their professional duties and responsibilities. It means that CLIL involves studying situations where subjects (or parts of subjects) are taught in a foreign language with dual-focused aims, namely the learning of content and the simultaneous learning of a FL in which this content is encoded. It is widely seen as an excellent means of learning a language, and of introducing global and intercultural aspects into the teaching of content subjects. It is claimed to be a very effective way of learning FL as it provides the learners with meaningful input and authentic situations. There is no doubt that learning a language and learning through a language is a concurrent process, nevertheless using the CLIL approach requires teachers and high school administrators' rethinking of the traditional concepts of FL teaching to students of non-linguistic specialities. The main conclusion to be drawn is that integration of CLIL approach is very effective in teaching FL and developing professional skills of the students at nonlinguistic higher educational institutions. Prospects for further research involve research of the opportunities of the introduction of the CLIL methodology in Ukraine.

Cambridge English. 10 Eurydice network Adult Education and Training in Europe / D. Coyle. - 2010. - Режим доступу:

http://eacea.ec.europa.eu/education/eurydice/documents/t hematic_reports/179EN.pdf

6. Dudley-Evans T. Developments in ESP: A multidisciplinary approach / T. Dudley-Evans, M. St. Johns. Cambridge: CUP, 1998. - $301 \mathrm{p}$.

7. English for Specific Purposes (ESP). National curriculum for universities. -Kyiv: Lenvit, 2005. - 108 p.

8. Marsh D. European Framework for CLIL Teacher Education / David Marsh, Peeter Mehisto, Dieter Wolff, María Jesús Frigols Martín. - Режим доступу: http://encuentrojournal.org/textos/9.\%20CLILFramework.pdf. 
9. Marsh D. CLTL / EMILE - the European dimension: actions, trends and foresights potential. - Brussels: The European Union, 2002.

10. Mehisto P. Uncovering CLIL: Content and language integrated learning in bilingual and multilingual education / P. Mehisto, D. Marsh, J. Frigols. - Oxford: Macmillan Education, 2008.

11. Nixon J. Quality in SPRINT: Towards quality assessment and assurance in content and language integrated education: A field report / J. Nixon. -Stockholm, 2001.

12. Spence P. Engineering English and the high-tech industry: A case study of an English needs analysis of process integration engineers at a semiconductor manufacturing company / P. Spence, Gi-Zen Liu // English for

\section{REFERENCES}

1. Bentley, K. (2010). The TKT Course CLIL module. Cambridge: CUP [in English].

2. Commission of the European Communities Promoting Language Learning and linguistic diversity. An action plan 2004-2006. (2003). Brussels [in English].

3. Coyle, D., Hood, Ph., \& Marsh, D. (2010). Content and language integrated learning. Cambridge: Cambridge University Press [in English].

4. Coyle, D. (1999). Theory and planning for effective classrooms: supporting students in content and language integrated learning contexts. J. Masih (Ed.). Learning through a foreign language. London: CILT [in English].

5. Coyle, D. (2010). Evaluating the impact of CLIL programmes: Content and language integrated learning. Cambridge English. 10 Eurydice network adult education and training in Europe. Retrieved from: http://eacea.ec.europa.eu/education/eurydice/documents/thematic_reports/179EN.pdf [in English].

6. Dudley-Evans, T., \& St. Johns, M. (1998). Developments in ESP: A multidisciplinary approach. Cambridge: CUP [in English].

7. English for specific purposes (ESP). National curriculum for universities (2005). Ministry of Education and Science of Ukraine. British Council Ukraine. Kyiv: Lenvit [in English].

8. Marsh, D., Mehisto, P., Wolff, D., Martin, M. J. F. (n.d.). European framework for CLIL teacher education / Council of Europe. Retrieved from: http://encuentrojournal.org/textos/9.\%20CLILFramework. pdf [in English].
Specific Purposes. - 2013. - Vol. 32. - Issue 2. - P. 97109. - Режим доступу: http://www.sciencedirect.com/science/ article/pii/S088949061200066X.14

13. Tarnopolskyi O. Constructivist blended learning approach to teaching English for Specific Purposes / O. Tarnopolskyi. - London: Versita, 2012. - 254 p.

14. Тарнопольский О. Б. Интеграция обучения языку и специальности в неязыковом вузе: монография / О. Б. Тарнопольский, 3. М. Корнева. -Заабрюкен: Lambert Academic Publishing, 2013. - 314 c.

15. "What is CLIL?" [Електронний ресурс]. - Peжим доступу: https://sites.google.com/a/xtec.cat/clilprinciples/what-is-clil

9. Marsh, D. (2002). CLIL/EMILE - The European Dimension: Actions, trends \& foresight potential. Brussels: European Commission [in English].

10. Mehisto, P., Marsh, D., \& Frigols, M. J. (2008). Uncovering CLIL: Content and language integrated learning in bilingual and multilingual education. Oxford: Macmillan Education [in English].

11. Nixon, J. (2001). Quality in SPRINT: Towards quality assessment and assurance in content and language integrated education: A field report. Stockholm [in English].

12. Spence, P. (2013). Engineering English and the high-tech industry: A case study of English needs analysis of process integration engineers at a semiconductor manufacturing company. English for Specific Purposes, 2, 97109. (Vol. 32.). Retrieved from: http://www.sciencedirect.com/science/ article/pii/S088949061200066X.14 [in English].

13. Tarnopolskyi, O. (2012). Constructivist blended learning approach to teaching English for Specific Purposes. London: Versita [in English].

14. Tarnopolskyi, O., \& Kornieva, Z. (2013). Integratsiya obucheniya yazyku i spetsialnosti $v$ neyazykovom vuze [The integration of teaching language and speciality at nonlinguistic higher educational institution]. Saarbrücken: LAP LAMBERT, Academic Publishing [in Russian].

15. "What is Clil?" (n.d.). Retrieved from: https://sites.google.com/a/xtec.cat/clil-principles/what-isclil [in English].

\section{Надія Володимирівна Грицик, \\ кандидат педагогічних наук, доцент кафедри іноземних мов, Чернігівський національний педагогічний університет імені Т. Г. Шевченка,} вул. Гетьмана Полуботка, 53, м. Чернігів, Украӥна

\section{ПРЕДМЕТНО-МОВНЕ ІНТЕГРОВАНЕ НАВЧАННЯ: ПІДХІД ДО НАВЧАННЯ АНГЛІЙСЬКОЇ МОВИ ЗА ПРОФЕСІЙНИМ СПРЯМУВАННЯМ}

У статті представлено опис предметно-мовного інтегрованого навчання (ПМІН) в контексті навчання іноземної мови у вищих навчальних закладах. ПМІН - це педагогічний підхід, який одночасно дозволяє засвоювати іноземну мову та предмет, тобто цей підхід передбачає таку навчальну діяльність, де мова використовується як інструмент для засвоєння нових знань $з$ професійної сфери або теми. Завдяки використанню вищезазначено- 
го підходу студенти отримують знання деяких спеціальних дисциплін та одночасно вдосконалюють мовні навички та вміння. ПМІН грунтується на так званому принципі «4С», який включає зміст (сприяє стимулюванню процесу засвоєння знань і розвитку вмінь з предмету); спілкування (допомагає навчати студентів використовувати засоби іноземну мову для отримання знань з предмету); мисленнєві здібності (допомагають розвивати здатність студентів до кращого розуміння мови і предмету); культурологічні знання (розуміння особливостей, подібностей та відмінностей окремих культур допоможе студентам ефективніше соціалізуватись у сучасному полікультурному суспільстві, краще зрозуміти власну культуру). Також ПМІН розглядається як ефективний інструмент навчання англійської мови за професійним спрямуванням і засіб мотивації студентів до подальшого навчання. За ПМІН, типовий урок складається з етапів, які включають такі види діяльності: перевірка засвоєних раніше знань, розширення словарного запасу, закріплення знань, застосування нових знань, перевірка та виправлення помилок. Інтеграція зазначеного підходу в навчальний процес вишу потребує від викладачів і керівників навчальних закладів переосмислення традиційних уявлень про викладання англійської мови студентам немовних спеціальностей. Авторка робить висновок про те, що реалізація ПМІН у процесі вивчення курсу англійської мови за професійним спрямуванням дозволить активізувати навчання іноземної мови та підвищить якість навчального процесу.

Ключові слова: предметно-мовне інтегроване навчання (ПМІН), принципи ПМІН, англійська мова за професійним спрямуванням, іноземна мова (IM), вищий навчальний заклад (ВН3).

Надежда Владимировна Грицык, кандидат педагогических наук, доцент кафедры иностранных языков, Черниговский нацииональный педагогический университет имени Т. Г. Шевченко, ул. Гетьма Полуботка, 53, г. Чернигов, Украина

\section{ПРЕДМЕТНО-ЯЗЫКОВОЕ ИНТЕГРИРОВАНОЕ ОБУЧЕНИЕ: ПОДХОД К ПРЕПОДАВАНИЮ АНГЛИЙСКОГО ЯЗЫКА ПРОФЕСИОНАЛЬНОЙ НАПРАВЛЕННОСТИ}

В статье представлено описание предметно-языкового интегрированного обучения (ПЯИО) в контексте обучения иностранному языку в высших учебных заведениях. ПЯИО - это педагогический подход, который одновременно позволяет усваивать иностранный язык и учебный предмет, то есть он предполагает такую учебную деятельность, где язык используется как инструмент для усвоения новых знаний в профессиональной сфере или теме. Благодаря использованию вышеуказанного подхода студенты получают знания специальных дисциплин и одновременно совершенствуют языковые навыки и умения. ПЯИО основывается на так называемом принципе «4С», который включает содержание (способствует стимулированию процесса усвоения знаний и развития умений по предмету), общение (помогает обучать студентов и использовать средства иностранного языка для получения знаний по предмету), мыслительные способности (помогают развивать способность студентов к лучшему пониманию языка и предмета), культурологические знания (понимание особенностей, сходств и различий отдельных культур поможет студентам более эффективно социализироваться в современном поликультурном обществе, лучше понять собственную культуру). Также ПЯИО рассматривается как эффективный инструмент обучения английскому языку по профессиональному направлению и средство мотивации студентов к дальнейшему обучению. Согласно ПЯИО, типичный урок состоит из этапов, которые включают следующие виды деятельности: проверка усвоенных ранее знаний, расширение словарного запаса, закрепление знаний, применение новых знаний, проверка и исправление ошибок. Интеграция указанного подхода в учебный процесс вуза требует от преподавателей и руководителей учебных заведений переосмысления традиционных представлений о преподавании английского языка студентам неязыковых специальностей. Автор делает вывод о том, что реализация ПЯИО в процессе изучения курса английского языка профессионального направления позволит активизировать обучение иностранному языку и повысит качество учебного процесса.

Ключевые слова: предметно-языковое интегрированное обучение (ПЯИО), принципы ПЯИО, английский язык профессионального направления, иностранный язык (ИЯ), высшее учебное заведение (ВУЗ).

Рецензент: д. пед. н., проф. І. В. Бужина

Подано до редакиії 06.12.2016 